This is an Authors' Original Version of an adaption from a book-chapter published by Leiden University on 5 February 2019.

\title{
Sixty-six Communicated Applications Vs. the Russian "Foreign Agents Act" at the European Court of Human Rights: A Global Dispute Resolution Mechanism in the Making?
}

\author{
Chris Wiersma* \\ email: chriswiersma@pm.me \\ chriswiersma.wordpress.com
}

\section{Introduction}

More and more submissions that challenge the Russian "Foreign Agents Act" are being sent to the European Court of Human Rights (ECtHR) in Strasbourg. 'In total, sixty-six proceedings are currently ongoing before the Court.ii

In this article, I add the perspective of European Human Rights (case) law in relation to the current state of the following cases that have been communicated by the ECtHR: Ecodefence a.o./Russia, and 48 other applications, iii Levada Centre/Russia, and 14 other applications, iv Mikushin/Russia, ${ }^{\text {" }}$ and Rudomakha and North Caucasus Environmental Watch/Russia. ${ }^{\text {vi }}$ In these communications, the ECtHR especially asks Russia to respond to complaints by an expansive number of (members of) NGOs (such as Ecodefence, Levada Centre, North Caucasus Environmental Watch and Eco-Logica). vii The first application was made in 2013, the most recent in 2018. viii These organizations were being forced to be listed

\footnotetext{
* My research fields include Media and Communications Law, and International (Human Rights) Law. I am a member of and support the International Society of Public Law (ICON-S, https://www.icon-society.org/ ), and the Dutch-Flemish Association for Investigative Journalists (VVOJ, https://gijn.org/member/dutch-flemishassociation-for-investigation-vvoj/ \& https://www.vvoj.org/ ). Also member of ad hoc Working Group "Best Practices on Platforms' Implementation of the Right to an Effective Remedy", part of the Dynamic Coalition on Platform Responsibility at the Internet Governance Forum (DCPR, https://www.intgovforum.org/multilingual/content/dynamic-coalition-on-platform-responsibility-dcpr ).
} 
in a State-controlled register under the label 'Foreign Agent'. As a consequence, these NGOs are struggling in their efforts to remain active and sustain themselves; sometimes they give up in liquidation because of the fear of exorbitant processing costs (or even the criminal conviction of individual persons). ${ }^{\text {ix }}$

We argued before that the case shows a worrying trend. ${ }^{x}$ In addition to this conclusion, I have analyzed also how, in relation to the communicated case of Ecodefence a.o./Russia, and 48 other applications, ${ }^{\mathrm{xi}}$ it is likely that the ECtHR will apply article 10 of the European Convention on Human Rights (ECHR) through its usual approach to conflicts related to news media content production. xii The Court's case-law contains a wide scope of protection of (the right to) freedom of expression that in my view can easily be related to certain activities that have been labeled by Russian authorities and courts as "political activities" of the applicants in Ecodefence and the other cases, such as by "preparing and distributing information on amendments to laws and views on State authorities' decisions and policy". xiii

On the global level, the adoption of aforementioned laws, as reported by Amnesty International, ${ }^{\text {xiv }}$ and the decline in political rights and civil liberties for the past 13 years, as monitored by Freedom House, ${ }^{x v}$ could threaten further freedom of expression and media freedoms. The challenges to counter these threats are copious. From the academic literature, it already can be learned that new transformations in the world of financing the activities of NGOs are underway in connection with lawmaker's efforts that are challenged as introduced above. Another international dimension is the question how to commonly deal with political influence of certain actors that can be exercised through political donations, and how to define legitimate state-concerns with "foreignness". xvi Laufer (2017) has proposed several key questions to critically assess how certain acts of the different countries have differing traits.

Remarking on the need to search for a responsive and viable mechanism of formal dispute resolution in the cross-border funding of NGOs context, Mayer (2018, p. 1265) has put forth to especially look at member state funded mechanisms such as regional human rights agreements. The ECHR likely holds the best option for a level-playing field in this context, although a fully tested outcome is lacking at the moment. ${ }^{x v i i}$

Further on, I argue that Article 10 of the ECHR (freedom of expression) is likely a viable trajectory in terms of the applicability of the European Treaty, in relation to the overall applications made by the applicants. I think there are some clear and troubling issues that the ECtHR will have to address in Ecodefence and the other cases, and I believe a Freedom of 
Expression/Press Freedom perspective is helpful. These areas are already hinted at in the 'Question to the Parties' for the next phase, and in my view can also be expected to play an important role in the direction in which the cases are moving.

I outline and discuss below all the communicated cases that challenge the Russian "Foreign Agents Act", which are available at the ECtHR. I also sketch how some other Treaty Articles are interlinked. The term "political activity" is central to the arguments raised here. I discuss separately how that term could be treated in light of the case law of the ECtHR about Article 16 of the ECHR at the end of this paper. ${ }^{\text {xviii }}$ In the conclusion, I sum up the remarks made in order to address the importance of these cases advancing at the ECtHR.

\section{A preliminary outline of the 4 Communicated Cases v. Russia}

As the European Court has affirmed that the applications against Russia submitted so far (i.e. Ecodefence a.o. and the other 48 merged applications, plus 17 more recent applications) require a decision, ${ }^{x i x}$ there is currently a substantive debate in Strasbourg on the issues that have been raised by these applications. This part of the article describes the hints that are made both in the individual cases of the applicants and in the questions directed to the parties by the ECtHR, and thereby looks ahead.

The applicants have asked the ECtHR to review certain 'restrictions'. ${ }^{\mathrm{xx}}$ This has been mentioned by most of the applicants in their request for judgment related to both Article 10 (freedom of expression) and Article 11 (freedom of assembly and association) in conjunction with Article 14 (the prohibition of discrimination) of the ECHR. The Questions-to-the-Parties paragraph in the Court's Communications specifies further, for example, that the Russian (governing) authorities imposed "the restriction of applicants' access to foreign funding" ( $Q 1$. (b)(ii)).

It is also clear that the issues revolve around several 'penalties' (cf. Article $10 \S 2$ ECHR). ${ }^{x \times i}$ As the European Human Rights Advocacy Centre (EHRAC) stated before the European Court, in relation to the applicant-NGOs it is representing before the ECtHR: "All of the NGO- 
applicants have been the subject of inspections and searches by the Prosecutor's offices with a view to determining whether they are to be classified as 'Foreign Agents'." xxii

Due to the legislation on non-governmental organizations which targets so-called NonCommercial Organizations (NCOs) which are funded from abroad, the applicants had to register in Russia. However, they were persecuted "for failing to register as foreign agents". In this context, we can also see that the applicants have been subjected to "formalities" and "conditions" (cf. Article $10 \S 2$ ECHR). Article 10 of the ECHR allows such requirements explicitly, but only insofar as they "are prescribed by law and are necessary in a democratic society", xxiii for certain legitimate "interests" or aims which are enumerated in a limited way in Article $10 \S 2$.

We could wonder here, as the ECtHR does, if the behavior of the so-called foreign agents was impacted by the registration-scheme. The Court has asked the parties: “(iii) Did registration as a foreign agent have an impact on the applicants' ability to freely express their ideas and carry out political activity? Was the suppression of the applicant organizations' free debate and political activities necessary in a democratic society?"

In my view, this question pinpoints the most fundamental issue, considering the Articles of the ECHR to which the applicants have referred. Russia will have to justify its (legislative) acts against the applicants in order to meet its obligations under the Convention. 30 NGOs have submitted that Russia has contravened Article 18 of the ECHR, which reads in full: "Limitation on use of restrictions on rights. The restrictions permitted under this Convention to the said rights and freedoms shall not be applied for any purpose other than those for which they have been prescribed."

At the European Court, all 66 applications contain the claim that Russia has subjected the applicants to excessive state control. This issue has been raised for example by Ecodefence, whose complaint is based upon an inspection performed by the Kaliningrad Region Justice Department, which resulted in a fine for the failure to register as a foreign agent, and also about the subsequent court rulings that endorsed the findings and decision to fine resulting from the inspection. ${ }^{x x v}$ Ecodefence claims, as well, that these measures have breached the right to freedom of expression protected by Article 10 of the ECHR. One of the causes, according to the complaints, is the substandard quality of the Russian legislation.

Ecodefence has asked for a review of these interferences in light of the Convention's prohibition of discrimination (Article $14 \mathrm{ECHR}$ ) and has also submitted the claim that its 
freedom of expression and association (Article 10 jo. 11 ECHR) was restricted for purposes other than those prescribed by the Convention (under Article $18 \mathrm{ECHR}$ ). According to the complaints, Ecodefence, as well as almost all of the other applicants, were being subjected "to discrimination and to restrictions and excessive reporting obligations", placed on the so-called Non-Commercial Organizations (defined by the NCOs Act; as amended by the "laws on nongovernmental organizations, collectively known as the 'Foreign Agents Act'"). They have noted finally that "other NGOs are exempt from such duties". ${ }^{x x v i}$

As it turns out from the case files, many different activities performed by the applicants have been discussed and labelled as "political activities" according to the impugned persecutions, and here it is helpful to cite a few exemplary ones:

“... (publishing information in the mass media, posting information on the Internet, public discussions and other public events, collecting signatures, and so on)..." (Regional Golos v. Russia, application no. 9988/13, lodged on 06.02.2013)

"by choosing the name 'Golos' Association for the Protection of Voting Rights' ..." (Golos Association v. Russia, application no. 9988/13, lodged on 06.02.2013)

"all the applicant's director's activities, interviews and comments to the press, in his capacity as director or independent expert on media law..." (Mass Media Defence Centre v. Russia, application no. 26169/16, lodged on 29.04.2016)

These conclusions were drawn by the inspection prosecutors and led to several obligations for the organizations, amongst which are several reporting obligations (such as labelling publications "as originating from a foreign agent" included with every instance of the dissemination of material in the media; made compulsory by section 24 of the NCOs Act). ${ }^{\text {xxvii }}$

The sanctions against the applicant-NGOs which have been imposed after these administrative processes are clear interferences with some of the rights of the applicants, most notably with freedom of expression in Article 10 of the ECHR and freedom of association in Article 11 of the ECHR. Another matter of Media Law that the applicants complained of and 
called "excessive" is the "reporting obligations". The applicants are focusing here on the relentless character of general, imposed obligations. In my view, these fall under scope of the protection that the European Convention provides.

\section{Versus Article 16 of the ECHR?}

As a follow-up to the Introduction, I end the discussion by looking into the applicability of Article 16 (restrictions on political activity of aliens) and the question as to whether this part of the European Convention could end up playing a role in exempting Russia from upholding its obligations, notably those under Article 10, 11 and 14 of the ECHR.

One of the key issues has been the interpretation of "political activity" both in the national legislation and in the development of the cases that have led to the requests made at the ECtHR. The term is linked to the concept of "foreign agent", which was introduced into section 2 of the NCOs Act in Russia in 2012. Substantially, a "foreign agent" is defined by its links with political activities. ${ }^{\text {xviii }}$

When looking at the Human Rights catalogue of the ECHR only, it is striking that "political activity" is indeed targeted by Article 16. The Court's case law related to this is very scarce. ${ }^{x x i x}$ The only recent (Grand Chamber) judgment that discussed this Article, makes it appear highly unlikely for this Article to have a profound effect on the possible balancing of the rights of applicants in Ecodefence against Russia's interests.

In Perinçek/Switzerland (Grand Chamber), ${ }^{\mathrm{xxx}}$ the Court discussed the applicability of Article 16 of the ECHR in relation to the criminal conviction of a Turkish national in Switzerland for a speech held in the context of a political rally, in particular under Article 10 of the ECHR (§ 117). The main reasoning and conclusion are as follows:

\footnotetext{
"Bearing in mind that clauses that permit interference with Convention rights must be interpreted restrictively (...), the Court finds that Article 16 should be construed as only capable of authorizing restrictions on 'activities' that directly affect the political process. This not being the case, it cannot be prayed in aid by the Swiss Government."
} $(\S 122)$ 
The reasoning here eliminates many chances for a different approach in Ecodefence and the other "Foreign Agents Act"-cases at the ECtHR as it deals with Article 10 specifically and head on. A similar approach to that found in Perinçek/Switzerland [GC] would lead to the same conclusion, that "Article 16 of the Convention did not authorize the ... authorities to restrict the applicant's exercise of the right to freedom of expression in this case" ( $\S 123)$.

In my opinion, Article 16 ECHR should be managed with a strong principled approach and similar outcome in these cases, if any argument would be raised about its justiciability. I foresee that it is otherwise highly unlikely that Article 16 ECHR will ever be a point of contention in the final deliberations of the judges who will look into judging the 66 caseproceedings submitted by the NGO-applicants at this stage.

\section{Conclusion}

I have considered a few roads that the sixty-six ongoing challenges against Russia in connection with that country's "Foreign Agents Act" could take.

If we are only addressing the area of media content production, for example, I see that: (1) there is almost no distinct way for the case to bump into a special margin for restrictions that member states of the Council of Europe could hope to rely on when dealing with the flow of information and capital from abroad that is impacting political activities in its territory, even when considering Article 16 of the ECHR; and (2) the ECtHR's case-law (with the due process requirements of Article 6 of the ECHR in mind as well) squarely points to the distinct applicability of Article 10 in relation to the NGOs' reporting obligations, the other discriminatory "restrictions", and all of the other penalties that impacted their research and media-related activities.

On a more general level, I believe the impugned classifications ${ }^{x \times x}$ of journalistic work and state-controlled monitoring, as described in the casefiles, do have a worrying and serious impact on the applicants' activities and, as well, on European societies. 
The main part of the article above is the Author's original version from "'Foreign

agents', 'aliens' or journalists? All should apply! (following recent cases in Media Law at the European Court of Human Rights)" by C. Wiersma. Adapted from Recht uit het

hart, edited by S. van der Hof et al., 2019 (Leiden University).

\title{
Endnotes \& Bibliography
}

\author{
${ }^{\mathrm{i}}$ http://hudoc.echr.coe.int/ \\ ii $\underline{\text { http://app.echr.coe.int/SOP/index.aspx?lg=en }}$ \\ iii ECtHR (communicated on) 22 March 2017, 9988/13 et al., (Communicated Case). \\ ${ }^{\text {iv }}$ ECtHR (communicated on) 19 June 2018, 16094/17 et al., (Communicated Case). \\ ${ }^{v}$ ECtHR (communicated on) 7 September 2018, 73715/17, (Communicated Case).

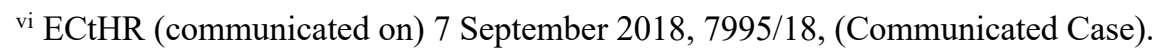

vii The European Human Rights Advocacy Centre (EHRAC), who represent part of the applicants, has listed 61 separate NGOs that applied together and form the Communicated Case of Ecodefence and Others v. Russia and 48 other applications: list at EHRAC, EHRAC.org.uk 2018, 12 March. At least 78 NGOs have applied to the ECtHR for a review through the submissions against Russia currently pending at the Court.

The UIA's definition of NGO is: 'A non-governmental organization (NGO) is a legally constituted organization created by private persons or organizations without participation or representation of any government. The term originated from the United Nations and is usually used to refer to organizations that are not conventional for-profit business. NGOs can be organized on a local, national or international level (INGO)', https://uia.org/faq.

viii Based on a search with the application number of the above-mentioned cases here: http://app.echr.coe.int/SOP/index.aspx $<<$ last consulted: 12 March 2019>>.

ix See also Tysiachniouk et al., Civil Society under the Law 'On Foreign Agents', 2018. See also EHRAC, EHRAC.org.uk 2018, 12 March.

${ }^{x}$ Wiersma \& Vesnic-Alujevic, (blog at) Blogactiv.eu 2017, 3 May, https://guests.blogactiv.eu/2017/05/03/thepress-is-foreign-and-fake-uppercuts-against-free-press-around-the-world/.

Almost in parallel, MPs in Hungary drafted a proposal of the Law on the transparency of civil organizations funded from abroad. Compare the timeline compiled by the Hungarian Civil Liberties Union (HCLU/TASZ) on this development, with several instances of governmental actions which target groups and organizations in similar ways as the above-mentioned Russian laws: HCLU, HCLU.hu 2017, 22 February.

This law is being challenged at the international level: CJEU (registered on) 1 June 2018, C-78/18 (Commission/Hungary). The European Commission has decided to refer its challenge against the Hungarian Law LXXVI of 2017 (on the transparency of organisations that receive financial support from abroad) to the Court of Justice of the EU for a declaration that Hungary had failed to fulfil its obligations under Article 63 TFEU and Articles 7, 8 and 12 of the Charter of Fundamental Rights of the European Union. See also: HCLU, HCLU.hu 2017, 13 April. 
Cf. also the opinion of the Hungarian Civil Liberties Union (HCLU/TASZ) on more recent (draft) laws made in Hungary that target groups and organisations in ways similar to the above-mentioned laws, while also trying to amend Hungary's Fundamental Law: HCLU, HCLU.hu 2018, 2 February; HCLU, HCLU.hu 2018, 5 June; HCLU, HCLU.hu 2018, 24 July.

${ }^{\text {xi }}$ ECtHR (communicated on) 22 March 2017, 9988/13, (Communicated Case).

See also the press releases and other documents provided by the European Human Rights Advocacy Centre (EHRAC) on its website, who represent some of the applicants: EHRAC, EHRAC.org.uk 2017, 12 April; 2013, 19 July; 2013, 7 February.

xii The main parts further in this article have originally been published as the book-chapter “'Foreign agents', 'aliens' or journalists? All should apply! (following recent cases in Media Law at the European Court of Human Rights)" by C. Wiersma, 2019.

The chapter served "as an homage to Wouter (A.W.) Hins and as a contribution to his liber amicorum for the occasion of his elevation to professor emeritus of Media Law at Leiden University."

There, I provide separately an overview of several cases (concluded with either a decision or judgment) at the ECtHR that dealt with conflicts concerning legal challenges against certain journalists' accreditation status. With regard to the (national) administrative processing of reviews around such conflicts, these cases provide, in my view, enlightening arguments that fit well into the characteristics of the Ecodefence case in its current stage.

xiii Golos Association v. Russia application no. 9988/13, lodged on 06.02.2013, see section APPENDIX - FACTS OF INDIVIDUAL CASES of ECtHR (communicated on) 22 March 2017, 9988/13, (Communicated Case).

xiv Amnesty International, Laws Designed to Silence, 2019.

${ }^{\mathrm{xv}}$ Freedom House, Democracy in Retreat, 2019.

xvi See for example, on the question "should foreign political donations be banned?": Tham, Money and Politics, 2017. And on the trend to extend the reach of US criminal law through more elements concerning the "foreign criminal": Lewis, When Foreign is Criminal, 2015.

${ }^{\text {xvii }}$ According to Meyer (2018, p. 1265-1266), <<the case brought by ... Russian NGOs challenging restrictions on cross-border funding of NGOs under the European Convention on Human Rights ... may provide a good test regarding whether the existing provisions of this regional human rights agreement are sufficient to successfully challenge such restrictions and therefore whether they are a viable protection with respect to the countries that are part of this agreements; if they prove to be, expanding the reach of such treaties may be the best way to protect cross-border funding of NGOs. $>>$ See also: Buyse 2018.

See also Van De Velde (2017) discussing the International Covenant on Civil and Political Rights (ICCPR)'s treaty-based mechanisms for resolving disputes.

xviii Article 16 of the European Convention of Human Rights (ECHR) reads in full: "Restrictions on political activity of aliens. Nothing in Articles 10,11 and 14 shall be regarded as preventing the High Contracting Parties from imposing restrictions on the political activity of aliens."

${ }^{\text {xix }}$ https://hudoc.echr.coe.int/eng\#\{\%22fulltext\%22:[\%22\\%22foreign\%20agents\%20act \\%22\%22]\}

The State-of-Proceedings search engine of the ECtHR provides up-to-date details on the dates of certain procedural steps related to cases that are pending or final at the Court, see: app.echr.coe.int/SOP/index.aspx.

\footnotetext{
${ }^{x x}$ See section COMPLAINTS of ECtHR (communicated on) 22 March 2017, 9988/13, Ecodefence a.o./Russia and 48 other applications (Communicated Case); or section SUBJECT MATTER OF THE CASES of ECtHR (communicated on) 19 June 2018, 16094/17, Levada Centre/Russia and 14 other applications (Communicated Case) or section QUESTIONS TO THE PARTIES of ECtHR (communicated on) 7 September 2018, 7995/18, Rudomakha and North Caucasus Environmental Watch/Russia (Communicated Case).

${ }^{x x i}$ These penalties against (some of) the applicants are described in the facts of individual applications, which are partly set out in Appendix of the Court's case-communication in connection with ECtHR (communicated on) 22 March 2017, 9988/13, Ecodefence a.o./Russia and 48 other applications (Communicated Case).
} 
xxii See the submission to the ECtHR made by the EHRAC in its letter dated 19 July 2013, which can be found on its website, see: EHRAC, EHRAC.org.uk 2013, 19 July.

xxiii I would put an emphasis on the word "democratic" here.

xxiv See section COMPLAINTS of ECtHR (communicated on) 22 March 2017, 9988/13, Ecodefence a.o./Russia and 48 other applications (Communicated Case); or the QUESTIONS TO THE PARTIES of ECtHR (communicated on) 19 June 2018, 16094/17, Levada Centre/Russia and 14 other applications (Communicated Case).

${ }^{x x v}$ The inspection led to the following opinion: "Actions taken to constitute political activities: Participating in protests against the construction of the Baltic Nuclear Power Station; promoting Russia's accession to the Aarhus Convention on Access to Information, Public Participation in Decision-Making and Access to Justice in Environmental Matters, and the Espoo Convention on Environmental Impact Assessment in a Transboundary Context; and contributing to the development of education and initiatives in the environmental field." See section APPENDIX - FACTS OF INDIVIDUAL CASES of ECtHR (communicated on) 22 March 2017, 9988/13, Ecodefence a.o./Russia and 48 other applications (Communicated Case).

xxvi See section COMPLAINTS of ECtHR (communicated on) 22 March 2017, 9988/13, Ecodefence a.o./Russia and 48 other applications (Communicated Case).

xxvii See sections RELEVANT DOMESTIC LAW AND PRACTICE and APPENDIX - FACTS OF INDIVIDUAL CASES of ECtHR (communicated on) 22 March 2017, 9988/13, Ecodefence a.o./Russia and 48 other applications (Communicated Case).

xxviii See section RELEVANT DOMESTIC LAW AND PRACTICE - A. Foreign Agents Act of ECtHR (communicated on) 22 March 2017, 9988/13, Ecodefence a.o./Russia and 48 other applications (Communicated Case).

xxix Based on the HUDOC, the online database for the Court's judgments, decisions and reports: http://hudoc.echr.coe.int/.

${ }^{x \times x}$ See $\S \S 118-123$ in ECtHR [GC] 15 October 2015, appl. no. 27510/08.

xxxi Remember the applicant Perinçek, whose case was admitted in Strasbourg, and who was "indeed an alien" according to the legal summary (in the part on '(a) Applicability of Article 16') provided at the CoE; see 'Information Note on the Court's case-law 189', (legal summary of) ECtHR (Grand Chamber) 15 October 2015, appl. no. 27510/08 (Perinçek/Switzerland).

$\underline{\text { Lists in connection with citations }}$

\section{List of cases}

Court of Justice of the European Union (CJEU)

- CJEU (registered on) 1 June 2018, C-78/18 Commission/Hungary (registered Case at http://curia.europa.eu/juris/liste.jsf?language $=\mathrm{EN} \&$ num $=\mathrm{C}-78 / 18$ ).

\section{European Court of Human Rights (ECtHR)}

- ECtHR (communicated on) 22 March 2017, 9988/13 et al., Ecodefence a.o./Russian and 48 other applications (Communicated Case at http://hudoc.echr.coe.int/eng?i=001-173049).

- ECtHR (communicated on) 19 June 2018, 16094/17, Levada Centre/Russia, and 14 other applications (Communicated Case at: http://hudoc.echr.coe.int/eng?i=001-184685 ). 
- ECtHR (communicated on) 7 September 2018, 73715/17, Mikushin/Russia (Communicated Case at: http://hudoc.echr.coe.int/eng?i=001-186588).

- ECtHR (communicated on) 7 September 2018, 7995/18, Rudomakha and North Caucasus Environmental Watch/Russia (Communicated Case at http://hudoc.echr.coe.int/eng?i=001-186589 ).

\section{List of other sources}

Journal-articles

Buyse, Squeezing civic space, 2018

A. Buyse 2018, 'Squeezing civic space: restrictions on civil society organizations and the linkages with human rights', International Journal of Human Rights, 22(8), pp. 966-988. https://doi.org/10.1080/13642987.2018.1492916

\section{Laufer, A Difference in Approach, 2017}

S. Laufer 2017, 'A Difference in Approach: Comparing the US Foreign Agents Registration Act with Other Laws Targeting Internationally Funded Civil Society', International Journal of Not-for-Profit Law, 19(1), pp. 5-11. http://www.icnl.org/research/journal/vol19iss1/Samantha\%20Laufer.pdf

Lewis, When Foreign is Criminal, 2015

M.K. Lewis 2015, 'When Foreign is Criminal', Virginia Journal of International Law, 55(3), pp. 626-684. https://ssrn.com/abstract $=2722608$

Mayer, Globalization Without a Safety Net, 2018

L. H. Mayer (2018), 'Globalization Without a Safety Net: The Challenge of Protecting Cross-Border Funding of NGOs', Minnesota Law Review, 102(3), pp. 1205-1271. http://www.minnesotalawreview.org/wpcontent/uploads/2018/02/Mayer_MLR.pdf

Tham, Of Aliens, Money and Politics, 2017

J.-C. Tham 2017, 'Of Aliens, Money and Politics: Should Foreign Political Donations Be Banned?', King's Law Journal, 28(2), pp. 262-278. https://doi.org/10.1080/09615768.2017.1351661

Tysiachniouk et al., Civil Society under the Law 'On Foreign Agents', 2018

M. Tysiachniouk, S. Tulaeva and L.A. Henry 2018, 'Civil Society under the Law 'On Foreign Agents': NGO Strategies and Network Transformation', Europe-Asia Studies, 70(4), pp. 615637.https://www.tandfonline.com/doi/pdf/10.1080/09668136.2018.1463512?needAccess=true

Van De Velde, The "Foreign Agent Problem", 2018

J. Van De Velde 2018, 'The "Foreign Agent Problem": an International Legal Solution to Domestic Restrictions on Non-Governmental Organizations', Cardozo Law Review, 40(2), pp. 687-747. http://cardozolawreview.com/wp-content/uploads/2019/01/VanDeVelde.40.2.5.pdf

Book-chapters

Wiersma, 'Foreign agents', 'aliens' or journalists? All should apply!, 2019

C. Wiersma, ''Foreign agents', 'aliens' or journalists? All should apply! (following recent cases in Media Law at the European Court of Human Rights)", in: Recht uit het Hart, edited by S. van der Hof et al., 2019 (Leiden University).

Reports

Amnesty International, Laws Designed to Silence, 2019

Amnesty International, amnesty.org 2019, 'Laws Designed to Silence: The Global Crackdown on Civil Society Organizations', Index number: ACT 30/9647/2019, https://www.amnesty.org/en/documents/act30/9647/2019/en/ 
Freedom House, Democracy in Retreat, 2019

Freedom House, freedomhouse.org 2019, 'Democracy in Retreat: Freedom in the World 2019', https://freedomhouse.org/report/freedom-world/freedom-world-2019/democracy-in-retreat

Blogs and other news-sources

EHRAC, EHRAC.org.uk 2013, 7 February

European Human Rights Advocacy Centre (EHRAC), EHRAC.org.uk 2013, 'Leading Russian Human Rights NGOs launch challenge at European Court to 'Foreign Agent Law', 7 February: http://ehrac.org.uk/news/leadingrussian-human-rights-ngos-launch-challenge-at-european-court-to-foreign-agent-law/ $<<$ last consulted: 12 March 2019>>.

EHRAC, EHRAC.org.uk 2013, 19 July

European Human Rights Advocacy Centre (EHRAC), EHRAC.org.uk 2013, 'New submission on the Foreign Agent Law', 19 July: http://ehrac.org.uk/news/submission-on-the-foreign-agent-law/ $<<$ last consulted: 12 March 2019>>.

EHRAC, EHRAC.org.uk 2017, 12 April

European Human Rights Advocacy Centre (EHRAC), EHRAC.org.uk 2017, 'European Court: Russia has case to answer on 'Law on Foreign Agents', 12 April: http://ehrac.org.uk/news/european-court-russia-has-case-to-answeron-law-on-foreign-agents/ $<<$ last consulted: 12 March 2019>>.

EHRAC, EHRAC.org.uk 2018, 12 March

European Human Rights Advocacy Centre (EHRAC), EHRAC.org.uk 2018, "The 'Foreign Agents Act' is stifling independent civil society", 12 March: http://ehrac.org.uk/news/foreign-agents-act-stifling-independent-civilsociety/ <<last consulted: 12 March 2019>>.

HCLU, HCLU.hu 2017, 22 February

HCLU, HCLU.hu 2017, 'Timeline of Governmental Attacks against Hungarian NGO Sphere', 22 February, https://tasz.hu/files/tasz/imce/timeline_of_gov_attacks_against_hu_ngos_22022017_1.pdf $<<$ last consulted: 12 March 2019>>

HCLU, HCLU.hu 2017, 13 April

Hungarian Civil Liberties Union (HCLU), HCLU.hu 2017, 'We are staying! HCLU will not be silenced!', 13 April: https://hclu.hu/en/articles/we-are-staying-hclu-will-not-be-silenced-1 <<last consulted: 12 March 2019>>.

\section{HCLU, HCLU.hu 2018, 2 February}

Hungarian Civil Liberties Union (HCLU), HCLU.hu 2018, 'Operation Starve and Strangle: how the government uses the law to repress Hungary's civic spirit', 2 February: https:/hclu.hu/en/articles/operation-starve-and-stranglehow-the-government-uses-the-law-to-repress-hungarys-civic-spirit-1 $<<$ last consulted: 12 March 2019>>.

\section{HCLU, HCLU.hu 2018, 5 June}

Hungarian Civil Liberties Union (HCLU), HCLU.hu 2018, 'HCLU position on the legislative proposals T-332 on the seventh amendment to Hungary's fundamental law and T-333 on the amendment of certain laws to combat illegal migration', 5 June: https://hclu.hu/en/articles/hclu-position-on-the-legislative-proposals-t-332-on-theseventh-amendment-to-hungarys-fundamental-law-and-t-333-on-the-amendment-of-certain-laws-to-combatillegal-migration <<last consulted: 12 March 2019>>.

HCLU, HCLU.hu 2018, 24 July

Hungarian Civil Liberties Union (HCLU), HCLU.hu 2018, 'Summary of the Hungarian Civil Liberties Union's analysis of the new bill on the right to assembly', 24 July: https:/hclu.hu/en/articles/summary-of-the-hungariancivil-liberties-unions-analysis-of-the-new-bill-on-the-right-to-assembly $<<$ last consulted: 12 March 2019>>.

Wiersma \& Vesnic-Alujevic, (blog at) Blogactiv.eu 2017, 3 May

C. Wiersma \& L. Vesnic-Alujevic, Blogactiv.eu 2017, 'The press is foreign and fake? Uppercuts against free press around the world', 3 May: https://guests.blogactiv.eu/2017/05/03/the-press-is-foreign-and-fake-uppercuts-againstfree-press-around-the-world/ $<<$ last consulted: 12 March 2019>>. 